\title{
Infectious endocarditis: interdisciplinarity or dual responsibility?
}

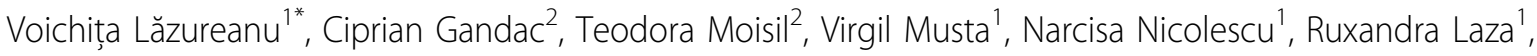 \\ Oana Plavitu², Alexandru Crişan ${ }^{1}$ \\ From The 10th Edition of the Scientific Days of the National Institute for Infectious Diseases "Prof Dr Matei Bals" \\ Bucharest, Romania. 15-17 October 2014
}

\section{Background}

Infectious endocarditis remains - due to its clinical polymorphism - a disease that is sometimes late diagnosed.

\section{Case report}

We present a man, 56 years, admitted in our department for tuberculous (TB) meningoencephalitis (history of pulmonary tuberculosis, symptoms: fever, dizziness, sleepy, difficulty in speaking and walking; in the CSF proteins $=62.1 \mathrm{mg} / \mathrm{dL}, 17$ lymphocytes $/ \mathrm{cmm}$, chest X-ray: nodular opacity in the upper left lobe, reticulo-nodular image bilaterally, pneumologist consult: pulmonary tuberculosis, secondary infiltrative nodular upper left lobe) with favorable evolution under treatment with: meropenem $2 \mathrm{~g}$ Q8h + category II 7/7 TB drugs. After 7 days from admission the blood culture tested positive for Streptococcus gallolyticus (BACTEC). The second cardiac examination revealed during transthoracic echography a $1.8 \mathrm{~cm}$ vegetation on the aortic valve. We switched to vancomycin $1 \mathrm{~g}$ Q12h plus tuberculostatics. Cardiac surgery consult recommends 4 weeks of treatment with vancomycin and then probably surgical intervention.

\section{Conclusion}

The laboratory has a very important role in the diagnosis of infectious diseases. A close contact with cardiologists has to be established in order to have carefully investigated patients.

\section{Consent}

Written informed consent was obtained from the patient for publication of this Case report and any

\footnotetext{
* Correspondence: vlazureanu@yahoo.com

'Dr. Victor Babeş University of Medicine and Pharmacy, Timişoara, Romania Full list of author information is available at the end of the article
}

accompanying images. A copy of the written consent is available for review by the Editor of this journal.

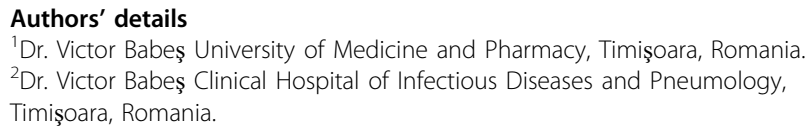

Published: 15 October 2014

doi:10.1186/1471-2334-14-S7-P37

Cite this article as: Lăzureanu et al:: Infectious endocarditis:

interdisciplinarity or dual responsibility? BMC Infectious Diseases 2014 14(Suppl 7):P37.
Submit your next manuscript to BioMed Central and take full advantage of:

- Convenient online submission

- Thorough peer review

- No space constraints or color figure charges

- Immediate publication on acceptance

- Inclusion in PubMed, CAS, Scopus and Google Scholar

- Research which is freely available for redistribution

Submit your manuscript at www.biomedcentral.com/submit

\section{() Biomed Central}

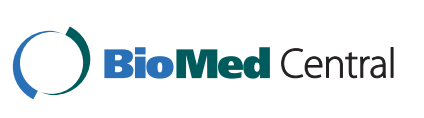

C 2014 Lăzureanu et al; licensee BioMed Central Ltd. This is an Open Access article distributed under the terms of the Creative Commons Attribution License (http://creativecommons.org/licenses/by/4.0), which permits unrestricted use, distribution, and reproduction in any medium, provided the original work is properly cited. The Creative Commons Public Domain Dedication waiver (http://creativecommons.org/publicdomain/zero/1.0/) applies to the data made available in this article, unless otherwise stated. 